\title{
Erratum to: Duodenal perforation by an inferior vena cava filter with staphylococcal bacteremia: a case report
}

Sunil Pokharel ${ }^{1 *}$, Catherine Bartholomew ${ }^{2}$ and Zhi Alan Cheng ${ }^{1}$

\section{Erratum}

Unfortunately, the original version of this article [1] contained an error. The third author's surname was incorrect. The corrected author name can be found below. The author's name has been corrected in the original article and is also included correctly below.

Zhi Alan Cheng is the correct name.

\begin{abstract}
Author details
'Department of Medicine, Albany Medical Center, 47 New Scotland Avenue, Mail Code 17, Albany, NY 12208, USA. ²Department of Gastroenterology, Albany Medical Center, 47 New Scotland Avenue, Mail Code 48, Albany, NY 12208, USA.
\end{abstract}

Published online: 23 June 2016

\section{Reference}

1. Pokharel S et al. J Med Case Rep. 2016;10:111. doi:10.1186/s13256-016-0901-z.

\footnotetext{
*Correspondence: pokhars@mail.amc.edu

'Department of Medicine, Albany Medical Center, 47 New Scotland Avenue, Mail Code 17, Albany, NY 12208, USA
}

Submit your next manuscript to BioMed Central and we will help you at every step:

- We accept pre-submission inquiries

- Our selector tool helps you to find the most relevant journal

- We provide round the clock customer support

- Convenient online submission

- Thorough peer review

- Inclusion in PubMed and all major indexing services

- Maximum visibility for your research

Submit your manuscript at www.biomedcentral.com/submit 